Bhúmi, The Planning Research Journal

Vol. 5, No. 2, December 2017

\title{
Management of Nominated Subcontractors in the Construction of Commercial Buildings in Sri Lanka
}

\author{
M.N.N. Rodrigo ${ }^{1}$ and B.A.K.S. Perera \\ Department of Building Economics, University of Moratuwa, Sri Lanka
}

\begin{abstract}
Construction industry employs Nominated Subcontractors (NSCs). However, all NSCs so employed may not possess the required expertise to fulfill the requirements of their clients. Various issues can arise due to the absence of proper nominated subcontracting practices making it necessary to manage the NSCs properly. Initially, a comparison of nominated subcontracting practices in Sri Lanka with those in several other countries was done. The method of selection of NSCs in Sri Lanka and the mode of payments made to them are same as those of other countries. Like in Sri Lanka, in other countries too, a subcontract is entered into between the Main Contractor (MC) and the NSC. However in Sri Lanka, the form of subcontract used has not been prepared to specifically suit the local requirements. There is also no compulsory subcontractor registration procedure and there is also no security for the payments made to the NSCs. Since often issues can arise with NSCs due to their improper selection, poor documentation of their work and for not properly making payments to them, solutions that will resolve those issues were identified from the literature and validated later for Sri Lanka through interviews and were ranked through a questionnaire survey. The most critical issue that can arise due to the improper selection of NSCs is 'Delays caused by the NSC' and the most suitable solution to resolve this issue is to 'Make the NSC's program to fall in line with the MC's program'. Similarly, the solution 'Prepare the specifications and the scope of work well' is identified to be the most important solution that will resolve the issue - 'Errors in documentation' - that can arise due to poor documentation. The findings furthermore revealed that the most critical issue that can arise for not making payments to NSCs properly are the 'Delays in approving the interim payment certificate' and the most important solution to resolve this issue is to 'Attend to joint measurements, joint records and joint reports prior to the submission of the application'.
\end{abstract}

Keywords: Commercial Buildings; Documentation; Nominated Subcontractor (NSC); NSC Selection; Payments; Sri Lanka.

\section{Introduction}

Subcontracting is generally used to get a specific and pre-determined type of construction work done by a party who is specialised in that particular type of construction work (Bennett and Ferry, 1990). According to Hughes et al. (1994), subcontracting is a mechanism for employing others without making them a part of one's own organization. Lai (2000) believed that subcontracting of construction work acknowledges the ability and the competence of the subcontractors to perform successfully, the construction work assigned to them.

The general increase in the trend for subcontracting has been driven by technological, political, social and economic changes (Karim et al., 2006). Hughes et al., 1994 declared that as technology becomes more and more complex, the type of skills

\footnotetext{
${ }^{1}$ Corresponding Author:

(iD) https://orcid.org/0000-0002-4542-8890

Email address: navomail@gmail.com, pererabaks@gmail.com

DOI: http://doi.org/10.4038/bhumi.v5i2.29
} 
needed becomes more diverse leading to specialisation in a particular area. Oseghale and Wahab (2014) were of the view that modern buildings are complex and that as a result they need to employ many specialist consultants and contractors. Similarly, Hughes et al. (1994) opined that the emergence of nominated subcontracting is mainly due to the increased sophistication of construction and the increasing needs of the clients. Letting work to subcontractors has therefore become a very common practice in the construction industry (Skaik and Al-Hajj, 2013; Arditi and Chotibhongs, 2005).

Generally, a large number of subcontractors are involved in building projects (Dow et al., 2009). A large numbers of Nominated Subcontractors (NSCs) are also involved in construction projects (Cho and Furusaka, 2015). As the main contractors tend to rely more and more on a large number of subcontractors, most of the construction work is assigned to subcontractors (McCord and Gunderson, 2014). Hence, subcontracting has reached its pinnacle and it will simply not be possible to avoid subcontracting in the future (Ofori, 1990). Karim et al. (2006) stated that subcontractors carry out approximately $90 \%$ of the construction work with the Main Contractor (MC), mostly focusing on the management and coordination of the work. Costantino et al. (2001) were of the opinion that due to the complexity of the projects involved, subcontracting would require the MC to manage and supervise the subcontractors all the time.

Yates and Hardcastle (2003) mentioned that the unsatisfactory management of subcontractors can lead to several problems such as conflicts and disputes among parties, quality issues, project delays, payment issues etc. According to Rahman (2006), many construction projects suffer from delays. These delays may be a result of a subcontractor's direct action or his failure to fulfil his duty by acting according to circumstances (Bramble and Callhan, 1992). Carnell (2005) stated that delays caused by NSCs disturb the progress of work considerably. Thus, the management of NSCs has to be done properly as it can have a bearing on the successful completion of projects in terms of their time, cost and quality (Chong, 1994). Therefore, this research focuses on the management of nominated subcontractors so that those conflicts and disputes can be avoided.

1.1 Need for research on the management of nominated subcontractors in Sri Lanka

All construction work involves either subcontracting or separate trades contracting (Hughes et al., 1994). Kwok and Hampson (1997) stated that approximately $80 \%$ to $90 \%$ of the value of work of a construction project is performed by subcontractors. This large proportion of work done by subcontractors gives rise to the need for examining how data can be collected and used for decision making purposes in the management and coordination activities (Karim et al., 2006).

In Sri Lanka, the subcontractor involvement is higher in the building construction sector (77.8\%) than in any other sector such as those related to highways, bridges, water supply and drainage systems, irrigation and land drainage systems etc., and the subcontractor involvement in the building sector has been the highest in the commercial buildings (Department of Census and Statistics, 2013). NSC involvement in the commercial building construction may also be higher. Thus, the management of nominated subcontracting practices in the 
construction of commercial buildings in Sri Lanka becomes important.

Both internationally and locally, there is only very little research that has been conducted on subcontracting. Some research has been conducted outside Sri Lanka on factors affecting subcontractor selection (Zou, and Lim, 2014), selection of domestic subcontractors

(Biong,

2013),

subcontractors' business relationship as risk sources (Artto, et al., 2008) and the influence of procurement on subcontractor involvement (Eriksson et al., 2007). Although some research related to subcontracting has been carried out by international researchers, their findings may not be fully relevant to the construction industry in Sri Lanka as the construction industry of one country can be different from that of another country.

Ganesharajah (1999) has done a research, in the Sri Lankan context, on the factors affecting the subcontractors' bidding decisions. Bandara (1999) through his research has suggested alternatives to the nominated subcontracting system and a research on factors affecting the quality of performance of subcontracting has been carried out by Attanayake (2012). However, the issues that can arise in the construction of commercial buildings in Sri Lanka due to improper selection of NSCs and poor documentation of their work as well as for not making properly the payments due to them have never been investigated into. It has to be noted that nominated subcontracting has an impact on the construction industry due to the large number of subcontracting firms that keep on emerging in the industry (Yik et al., 2006) as all NSCs may not have the expertise needed to fulfil their clients' requirements successfully (Humphreys et al., 2003). Furthermore, as no research has been conducted on nominated subcontracting practices in Sri Lanka and the issues related to the management of NSCs, there is a research gap. This makes it necessary to study and compare existing nominated subcontracting practices in Sri Lanka with those in other countries. This will help to identify issues that can arise due to improper selection of NSCs and poor documentation of their work and also for failing to make the payments due to them properly and identify the most appropriate solution to resolve each of these issues so that nominated subcontracting practices could be properly managed.

\section{Literature synthesis}

\subsection{Subcontracting}

Subcontracting is defined as the employment of a firm or a person outside the main company for working on latter's behalf (Oxford dictionary, 2015). Bennett and Ferry (1990) stated that subcontracting refers to the performance of specific and pre-determined types of construction work by a party who is specialised in the type of construction work required. There are two main categories of subcontractors, namely domestic subcontractors and nominated subcontractors. According to Mbachu (2008), a domestic subcontractor is hired by the $\mathrm{MC}$ at his own discretion to perform a particular set of tasks whereas a

NSC is nominated by the client or the client's agent to undertake specified tasks set out in the main contract. Hinze and Tracey (1994) stated that all subcontractors have to be obliged to the MC contractually. Artto et al. (2008) said that when the NSC has to report directly to the client, it may not only affect adversely the execution of the project but that it may also pose a potential risk for the MC in that he can get bypassed by the NSC. 
Direct contracting cannot therefore be recommended. The NSCs too prefer to enter into subcontracts with the MC (Murdoch and Hughes, 2000).
The subcontractor and the NSC have been defined in various forms of contracts and forms of subcontracts as illustrated in Table 1.

\begin{tabular}{|c|c|c|}
\hline Defined Term & Definition & Reference \\
\hline Subcontractor & $\begin{array}{l}\text { Any person named in the Contract as a } \\
\text { subcontractor or any person appointed as a } \\
\text { subcontractor, for a part of the Works }\end{array}$ & $\begin{array}{l}\text { Standard Bidding Document, SBD- } \\
\text { 2, } 2007\end{array}$ \\
\hline Subcontractor & $\begin{array}{l}\text { The person named as subcontractor in the } \\
\text { Appendix to Subcontractor's Offer accepted by } \\
\text { the Contractor }\end{array}$ & $\begin{array}{l}\text { FIDIC Conditions of Subcontract, } \\
2011\end{array}$ \\
\hline Subcontractor & $\begin{array}{l}\text { Any person named in the Contract as a } \\
\text { subcontractor or any person appointed as a } \\
\text { subcontractor, for a part of the Works }\end{array}$ & $\begin{array}{l}\text { FIDIC Conditions of Contract, } \\
1999\end{array}$ \\
\hline Subcontractor & $\begin{array}{l}\text { A person or organization who has a contract with } \\
\text { the Contractor to } \\
\text { - construct or install part of the Works; } \\
\text { - provide a service necessary to provide } \\
\text { the Works; } \\
\text { - Supply Plant and Materials which the } \\
\text { person or organization has wholly or } \\
\text { partly designed specifically for the } \\
\text { Works. }\end{array}$ & $\begin{array}{lcr}\text { NEC3 } & \text { Engineering } & \text { and } \\
\text { Construction Contract, 2013 } & \end{array}$ \\
\hline $\begin{array}{l}\text { Sub- } \\
\text { Contractor }\end{array}$ & $\begin{array}{l}\text { The person named as Sub-Contractor in the Sub- } \\
\text { Contract Agreement }\end{array}$ & $\begin{array}{l}\text { The Joints Contracts Tribunal } \\
\text { (JCT) Intermediate Named Sub- } \\
\text { Contract, } 2016 \\
\text { JCT Intermediate Sub-Contract, } \\
2016 \\
\text { JCT Standard Building Sub- } \\
\text { Contract, } 2016\end{array}$ \\
\hline $\begin{array}{l}\text { Nominated } \\
\text { Subcontractor }\end{array}$ & $\begin{array}{l}\text { A Subcontractor (a) who is stated in the Contract } \\
\text { as being a nominated Subcontractor, or (b) whom } \\
\text { the Engineer, under Clause } 13 \text { [Variations and } \\
\text { Adjustments], instructs the Contractor to employ } \\
\text { as a Subcontractor }\end{array}$ & $\begin{array}{l}\text { Standard Bidding Document, SBD- } \\
\text { 2, } 2007\end{array}$ \\
\hline $\begin{array}{l}\text { Nominated } \\
\text { Subcontractor }\end{array}$ & $\begin{array}{l}\text { A Subcontractor (a) who is stated in the Contract } \\
\text { as being a nominated Subcontractor, or (b) whom } \\
\text { the Engineer, under Clause } 13 \text { [Variations and } \\
\text { Adjustments], instructs the Contractor to employ } \\
\text { as a Subcontractor }\end{array}$ & $\begin{array}{l}\text { FIDIC Conditions of Contract, } \\
1999\end{array}$ \\
\hline
\end{tabular}

Table 1. Definitions given for subcontractor and the Nominated Subcontractor

It is evident that most standard forms of contract mainly identify only the subcontractors and that NSCs are not straight away highlighted in all of the standard forms of contract.

\subsection{Selection of Nominated Subcontractors}

Different types of NSCs handling various specialised work (mechanical, plumbing, electrical, aluminium work etc.) have entered the construction industry during the past 
several years (Thomas et al., 2003). Costantino et al. (2001), Dow et al. (2009), Artto et al. (2008) and Enshassi et al. (2010) stated that subcontractor selection would be critical for the success of a project. Therefore, the selection of the most appropriate subcontractor for the type of construction works involved is important (Hughes et al., 1994). Furthermore, Artto et al. (2008) have recommended the binding of the subcontractors to the $\mathrm{MC}$ at the initial stage itself to ensure a technically and commercially competitive tender, early knowledge sharing and benefits for all concerned. Thus, it is necessary to manage the NSCs from the time of their selection itself.

\subsection{Documentation of the Work of Nominated Subcontractors}

The documentation produced during the design and construction stages include architectural and engineering drawings, contracts, subcontracts, specifications, purchase orders, requests for information, site instructions, architect's instructions, variation orders, general project correspondence and operation and maintenance manuals (Mena et al., 2010). According to Ryder et al. (2013), the construction industry admits that at present there are many errors and omissions in contract documentation and that inadequate, dubious and deficient design documentation is a significant underlying cause that makes projects inefficient. Therefore, it is necessary to identify the issues that arise from the poor documentation of NSC's works and determine how they could be resolved.

\subsection{Payments Made to Nominated Subcontractors}

Generally, the financial capacity of a NSC is comparatively lower than that of a MC (Matthews et al., 1996). Hence, timely payments made to a NSC will protect him from liquidation (Wong and Cheah, 2004). The employer makes payments to the MC in accordance with the general contractual arrangements related to NSC's works and the MC in turn makes the payments to the NSC unless when there is provision for the employer to make payments direct to the NSC (Murdoch and Hughes, 2000). The employer paying the $\mathrm{MC}$ and the MC paying the NSC is known as 'pay when paid' (Cheng et al., 2009). 'Set-off' is another significant term related to payments made to NSCs. It relates to the situation in which a MC raises a counterclaim against a subcontractor's claim or in which the employer raises a counterclaim against a MC's claim (Kennedy et al., 1997). As the NSC's financial capacity is comparatively lower, it is important to resolve the issues that arise from payments made to NSCs.

\subsection{Nominated Subcontracting Practices in Other Countries}

A study of nominated subcontracting practices in Singapore, United Kingdom (UK), Hong Kong and Australia was carried out. Australia and United Kingdom were selected to identify the nominated subcontracting practices, as the education and practices related to the construction industry in Sri Lanka are similar to those of these two countries. In addition, it is a common practice in Sri Lanka to use the standard documents published by these two countries. Singapore and Hong Kong were selected since there is research that has been conducted on subcontracting in these two 
countries and because many research papers are available from which the information could be collected. The findings revealed that nominated subcontracting practices vary from one country to the other. In all four countries, a subcontract is entered into between a MC and a NSC but the selection procedure, the form of subcontract used, subcontractor registration and security of payments are different from one another. An elaborate comparison has been carried out in this regard and the results are presented in Table 2.

\begin{tabular}{|c|c|c|c|c|}
\hline \multirow{2}{*}{$\begin{array}{l}\text { Nominated } \\
\text { Subcontracting } \\
\text { Practices }\end{array}$} & \multicolumn{4}{|c|}{ Practices } \\
\hline & Singapore & UK & Hong Kong & Australia \\
\hline $\begin{array}{l}\text { Method of } \\
\text { selection of the } \\
\text { NSC }\end{array}$ & $\begin{array}{l}\text { Selective tendering } \\
\text { and direct } \\
\text { negotiations (Kian, } \\
\text { 2000) }\end{array}$ & $\begin{array}{l}\text { Selective } \\
\text { tendering and } \\
\text { direct } \\
\text { negotiations } \\
\text { (Uher and } \\
\text { Davenport, 2009). }\end{array}$ & $\begin{array}{l}\text { Selective tendering } \\
\text { (Yik et al., 2006). }\end{array}$ & $\begin{array}{l}\text { Selective } \\
\text { tendering, open } \\
\text { tendering and } \\
\text { direct } \\
\text { negotiations (Zou } \\
\text { and Lim, 2006). }\end{array}$ \\
\hline $\begin{array}{l}\text { A subcontract is } \\
\text { signed between the } \\
\text { MC and the NSC }\end{array}$ & \multicolumn{4}{|c|}{$\begin{array}{l}\text { A nominated subcontract is formed between MC and NSC (Wong and Cheah, 2004; } \\
\text { Kennedy et al., 1997; Yik et al., 2006; Zou and Lim, 2006) }\end{array}$} \\
\hline $\begin{array}{l}\text { Use of Forms of } \\
\text { Subcontract }\end{array}$ & $\begin{array}{l}\text { Private sector } \\
\text { projects-Singapore } \\
\text { Institute of } \\
\text { Architects (SIA) } \\
\text { Subcontract } \\
\text { Public sector } \\
\text { projects-Standard } \\
\text { Conditions of } \\
\text { Nominated } \\
\text { Subcontract (Kian, } \\
\text { 2000) }\end{array}$ & $\begin{array}{l}\text { Sub-Contractors } \\
\text { and Specialist } \\
\text { Association } \\
\text { (SCSA) } \\
\text { Subcontract } \\
(1989)\end{array}$ & $\begin{array}{l}\text { Private projects- } \\
\text { Standard form of } \\
\text { Building Contracts } \\
2005 \\
\text { Nominated } \\
\text { Subcontract } \\
\text { Public projects- } \\
\text { General Conditions } \\
\text { of Contract for } \\
\text { Building Works- } \\
\text { 1999 (Yik et al., } \\
\text { 2006). }\end{array}$ & $\begin{array}{l}\text { Australian } \\
\text { Building Industry } \\
\text { Contract (ABIC) } \\
\text { Subcontract } \\
\text { Forms (Sharkey, } \\
\text { Bell, Jocic and } \\
\text { Marginean, } \\
\text { 2014). }\end{array}$ \\
\hline $\begin{array}{l}\text { Subcontractor's } \\
\text { registration with a } \\
\text { regulatory body }\end{array}$ & $\begin{array}{l}\text { Listed in the } \\
\text { Singapore List of } \\
\text { Trade } \\
\text { Subcontractors } \\
\text { (Loh and Ofori, } \\
\text { 2000). }\end{array}$ & $\begin{array}{l}\text { Registered under } \\
\text { Construction } \\
\text { Industry Scheme } \\
\text { (Greenwood, } \\
\text { 2010) }\end{array}$ & $\begin{array}{l}\text { Registered with the } \\
\text { Construction } \\
\text { industry Council of } \\
\text { Hong Kong } \\
\text { (Construction } \\
\text { Industry Council, } \\
\text { 2013) }\end{array}$ & $\begin{array}{l}\text { A separate } \\
\text { registration } \\
\text { system is } \\
\text { maintained under } \\
\text { each state } \\
\text { government }\end{array}$ \\
\hline $\begin{array}{l}\text { Pay when paid } \\
\text { concept }\end{array}$ & \multicolumn{4}{|c|}{$\begin{array}{l}\text { Pay when paid concept is practised in these countries unless when the employer } \\
\text { decides to make direct payments to NSC (Debrah and Ofori, 1997; Cunningham, } \\
\text { 2013; Zou and Lim, 2006). }\end{array}$} \\
\hline $\begin{array}{l}\text { Security of } \\
\text { Payment }\end{array}$ & $\begin{array}{l}\text { Available and is } \\
\text { governed by } \\
\text { Building and } \\
\text { Construction } \\
\text { Security of } \\
\text { Payment Act No } \\
57 \text { of } 2004\end{array}$ & $\begin{array}{l}\text { Available and is } \\
\text { governed by } \\
\text { Housing Grants, } \\
\text { Construction and } \\
\text { Regeneration Act } \\
1998\end{array}$ & $\begin{array}{l}\text { Has been proposed } \\
\text { by Development } \\
\text { Bureau of Hong } \\
\text { Kong (2015) but is } \\
\text { yet to be } \\
\text { implemented }\end{array}$ & $\begin{array}{l}\text { Available with } \\
\text { each state } \\
\text { governed by its } \\
\text { own acts. }\end{array}$ \\
\hline
\end{tabular}

Table 2. Nominated subcontracting practices in other countries 


\section{Research methodology}

The methodology used for this research comprised of two stages, namely an exploratory survey based on literature review and interviews; and a questionnaire survey.

An extensive literature synthesis was carried out during Stage I to learn about subcontracting and to achieve the first three objectives of the research, namely to understand nominated subcontracting practices in Sri Lanka and several other countries and to compare them with one another, to identify the current issues related to nominated subcontracting that have arisen in the construction of commercial buildings in Sri Lanka and to identify solutions that will resolve the issues so identified. However, the literature findings were on subcontractors in other countries. The findings therefore had to be validated for the NSCs in Sri Lanka. In this regard, four face to face semi-structured interviews were carried out with experienced practitioners to enable the validation of the literature findings. During the interviews, the interviewees also provided additional information. The details of the interviewees are given in Table 3. Du Toit and Mouton (2013) justified this approach because it takes the form of an exploratory and rigorous examination of real-life contexts and the interviewees could relate these literature findings to their own experience in the construction industry. The data collected through the interviews were analysed using code based content analysis software NVIVO.

\begin{tabular}{|c|c|c|c|c|}
\hline & $\begin{array}{l}\text { Interviewee A } \\
\text { (IA) }\end{array}$ & $\begin{array}{l}\text { Interviewee B } \\
\text { (IB) }\end{array}$ & $\begin{array}{l}\text { Interviewee C } \\
\text { (IC) }\end{array}$ & $\begin{array}{l}\text { Interviewee D } \\
\text { (ID) }\end{array}$ \\
\hline Post & $\begin{array}{l}\text { Chartered Quantity } \\
\text { Survevor }\end{array}$ & $\begin{array}{l}\text { Chartered Quantity } \\
\text { Survevor }\end{array}$ & $\begin{array}{l}\text { Chartered Quantity } \\
\text { Survevor }\end{array}$ & $\begin{array}{l}\text { Chartered Quantity } \\
\text { Survevor }\end{array}$ \\
\hline Type of & Consultancy & Consultancy & Contractor & Contractor \\
\hline Organization & Organization & Organization & Organization & Organization \\
\hline Designation & Director & Director & Director & $\begin{array}{l}\text { Chief Quantity } \\
\text { Surveyor }\end{array}$ \\
\hline Experience & 24 years & 23 years & 23 years & 26 years \\
\hline $\begin{array}{l}\text { Experience in } \\
\text { Subcontracting }\end{array}$ & 18 years & 17 years & 16 years & 20 years \\
\hline $\begin{array}{l}\text { Number of } \\
\text { projects } \\
\text { through which } \\
\text { there was an } \\
\text { involvement } \\
\text { with a NSC }\end{array}$ & 80 & 82 & 68 & 55 \\
\hline
\end{tabular}

Table 3. Details of interview respondents 
A standardized set of questions gives good results in a questionnaire survey which frequently contains questions beginning with the words who, what, where, how much and how many (Saunders et al., 2009). Since in this case, the questionnaire survey was found to be the most suitable option for data collection, in Stage II of this study a questionnaire survey was carried out to rank the issues and solutions in order to identify the most critical issue and also the most important solution that will resolve that particular issue. The questions in the questionnaire survey included several issues and the solutions most suitable for them. The respondents were asked to rank the criticalness of each issue using the Likert scale (1-not critical, 2-least critical, 3somewhat critical, 4-critical, 5-very critical) and to rank the importance of the solution also using the Likert scale (1-not important, 2-least important, 3-somewhat important, 4important, 5-very important). The five point Likert scale has been used in many previous researches (Sivakumaran et al., 2015; Ekanayake and Perera, 2016, Anuruddika et al., 2016). Mean rating (MR) was used to evaluate the collected data to find out the criticality of the issue and the importance of the solution that will resolve that issue and the formula for MR that has been used by Kamarazaly (2007), Sivakumaran et al. (2015) and Ekanayake and Perera (2016) is as follows:

$$
M R=\sum_{i=1}^{5}(F i x \% R)
$$

Here MR= Mean Rating for an attribute; $\mathrm{Fi}=$ Frequency of responses for an attribute (ranging from 1-5) and \%R= Percentage response to a rating point of an attribute.
The questionnaire contained close ended questions. It was distributed among 82 professionals working both in Sri Lanka and overseas with experience in working in the construction industry in Sri Lanka. Only 55 of them responded to all questions resulting in a response rate of $67 \%$. The respondents were selected through convenience sampling and due to time constraints only a limited number of questionnaires could be distributed. They were hand delivered to the local respondents and were emailed to overseas respondents. After the questionnaires were hand delivered, the local respondents were interviewed personally to collect data accurately within the limited time. The respondents were quantity surveyors, architects, engineers and project managers working in the construction industry each with an industry experience of 5 years or more. The professional background of the respondents is illustrated in Figure 1.

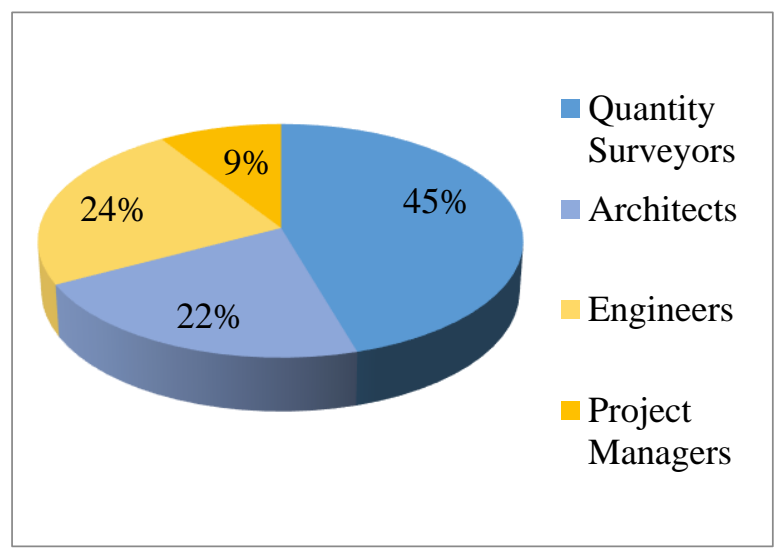

Figure 1. Professional background of the respondents 


\section{Research findings and their analysis}

\subsection{Comparison of Nominated} Subcontracting Practices in Sri Lanka with those in Other Countries

Initially, an extensive literature synthesis was carried out to identify the nominated subcontracting practices in other countries (Singapore, UK, Hong Kong and Australia) and the findings are presented in Table 2.
Subsequently, semi-structured interviews and a questionnaire survey were carried out to compare the practices in each of these countries with those in Sri Lanka. The findings of the interviews and the questionnaire survey were thereafter summarized as presented in Table 4 to demonstrate the nominated subcontracting practices in Sri Lanka.

\begin{tabular}{|l|l|l|}
\hline \multirow{2}{*}{$\begin{array}{l}\text { Nominated Subcontracting } \\
\text { Practices }\end{array}$} & \multicolumn{2}{c|}{ As Practised in Sri Lanka } \\
\cline { 2 - 3 } $\begin{array}{l}\text { Method of selection of the } \\
\text { NSC }\end{array}$ & $\begin{array}{l}\text { Interviews } \\
\text { Mostly Selective tendering } \\
\text { followed by direct } \\
\text { negotiations }\end{array}$ & $\begin{array}{l}\text { Selective tendering-51\% } \\
\text { Direct negotiations-42\% } \\
\text { Open tendering-7\% }\end{array}$ \\
\hline $\begin{array}{l}\text { A subcontract is signed } \\
\text { between the MC and the } \\
\text { NSC }\end{array}$ & Yes & $\begin{array}{l}\text { Yes - 67\% } \\
\text { No - 33\% }\end{array}$ \\
\hline $\begin{array}{l}\text { Use of Forms of } \\
\text { Subcontract }\end{array}$ & $\begin{array}{l}\text { Mostly FIDIC Conditions } \\
\text { of Contract }\end{array}$ & $\begin{array}{l}\text { FIDIC Form of Subcontract - 63\% } \\
\text { Other - 23\% } \\
\text { JCT Short Form of Subcontract 2011 - 9\% }\end{array}$ \\
& & $\begin{array}{l}\text { JCT Intermediate Named Subcontract } \\
2011-2 \% \\
\text { NEC 2013 ECS - 2\% } \\
\text { JCT Intermediate Subcontract 2011 - 1\% }\end{array}$ \\
\hline $\begin{array}{l}\text { Subcontractor's } \\
\text { registration with a } \\
\text { regulatory body }\end{array}$ & Not registered with CIDA & $\begin{array}{l}\text { No - 76\% } \\
\text { Yes - 24\% }\end{array}$ \\
\hline $\begin{array}{l}\text { Pay when paid concept is } \\
\text { followed }\end{array}$ & Yes & $\begin{array}{l}\text { Yes - 65\% } \\
\text { No - 35\% }\end{array}$ \\
\hline Security of Payment & No & $\begin{array}{l}\text { No - 62\% } \\
\text { Yes - 38\% }\end{array}$ \\
\hline
\end{tabular}

Table 4. Nominated subcontracting practices in Sri Lanka

As seen from Table 2 and Table 4, there are similarities as well as differences between nominated subcontracting practices in Sri Lanka and those in other countries. The method of selection of the NSCs, the type of the form of subcontract signed by the MC and the NSC and the mode of payments made to the NSCs (pay when paid) in Sri Lanka are similar to those in the other countries (Singapore, UK, Hong Kong and Australia). However, there are major differences as well. In Sri Lanka, there is no specific form of subcontract developed to suit the type of projects implemented in the country. According to the interviewees, this is a major drawback of the construction industry in Sri Lanka. Interviewee (IA) said that the Construction Industry Development Authority (CIDA) should publish a suitable form of subcontract to minimise the impact of the prevailing issues on the construction industry.

Interviewees IA, IB and IC were of the view that subcontractor registration should be made compulsory to improve the status of the subcontractors in the country. Interviewee IB further said that a regulatory body should take the responsibility for monitoring subcontractor registration and for updating the relevant information periodically. 
Interviewee IC was also of the view that there has to be a mechanism to ensure the security of the payments made and that action is required to implement that mechanism successfully. Interviewees IA and IB were also of the view that the construction industry in Sri Lanka is very informal as compared to those of any other country due to the absence of any mandatory nominated subcontracting practices. Thus, the government needs to take necessary action to rectify the weaknesses of the existing nominated subcontracting practices.

The questionnaire survey validates the findings from the interviews as most findings of the questionnaire survey are similar to the findings of the interviews except for the form of subcontract used in the construction industry in Sri Lanka. The interviewees opined that when preparing a subcontract, the practice used by them is to prepare a custom made subcontract by referring to the FIDIC Conditions of Contract depending on the requirement of the project. However, this method was not much recommended by the interviewees themselves due to its drawbacks and disputes which could arise at the end. From the findings of the questionnaire survey, it was revealed that the FIDIC Form of Subcontract 2011 is being mostly used, followed by 'other' forms of subcontract. 'Other' mentioned in the Table refers to the Forms of Subcontracts prepared by the organizations themselves for their use as there is no form of subcontract issued by the government to be used by the construction industry in Sri Lanka.

$24 \%$ of the respondents of the questionnaire survey have stated that the subcontractors were registered with a regulatory body (CIDA). The main reason for this is the fact that some of the large scale subcontractors have to be registered with CIDA as contractors, since CIDA grading is a requirement to be eligible to bid for certain major projects. However, most of the subcontractors have not registered with CIDA.

Similarly, although $38 \%$ of the respondents of the questionnaire survey opined that there is security of payment for subcontractors, it is not the case. The government has neither implemented nor developed a Security of Payment Act as yet. Thus, it appears that the respondents are not that knowledgeable on the term 'security of payment'.

On the other hand, to mitigate or resolve altogether the issues that can arise due to improper nominated subcontracting practices, the parties need to act thoughtfully. Hence, the issues that can arise due to the improper selection of NSCs, poor documentation of their work and for not making payments to them properly and the solutions that will resolve these issues were identified.

\subsection{Current Issues related to Nominated Subcontracting in the Construction of Commercial Buildings in Sri Lanka and the Solutions that will resolve them}

Various issues can arise due to improper selection of NSCs, poor documentation and improper payment modes. Solutions that will resolve these issues were identified from the literature and interviews which enabled the achievement of the second and third objectives. The issues and solutions that were identified from the interviews are highlighted in bold text in Tables 5, 6 and 7. The issues and solutions identified from the literature mainly focused on general subcontracting in other countries. Thus, the interviews assisted in validating the findings revealed from the literature to nominated subcontracting in Sri Lanka. 
4.3 Criticalness of Issues that can arise due to the Improper Selection of the NSCs and the Importance of the Solutions that will resolve these Issues

During the questionnaire survey, the respondents were requested to rank the issues and solutions that will resolve these issues, in order to identify the criticalness of the issues and the importance of the solutions. This was towards achieving the final objective. Table 5 presents the criticalness of the issues that can arise due to the improper selection of the NSCs and the importance of the solutions that will resolve those issues. Some of the issues and solutions were identified by Rodrigo and Perera (2016). However some changes have been done to the previously published context as illustrated in Table 5.

\begin{tabular}{|c|c|c|c|c|c|}
\hline Issue & MR & 蔍 & Solutions & MR & 压 \\
\hline \multirow[t]{4}{*}{$\begin{array}{l}\text { Delays caused } \\
\text { by the NSC }\end{array}$} & \multirow[t]{4}{*}{4.64} & \multirow[t]{4}{*}{1} & $\begin{array}{l}\text { Make the NSC's program to fall in line with the MC's } \\
\text { program }\end{array}$ & 4.31 & 1 \\
\hline & & & $\begin{array}{l}\text { Allow clauses related to liquidated damages or/and penalties } \\
\text { in the tender document }\end{array}$ & 4.20 & 2 \\
\hline & & & Get the NSC to have a proper program & 3.98 & 3 \\
\hline & & & $\begin{array}{l}\text { Conduct a background study to verify the NSCs' history of } \\
\text { work }\end{array}$ & 3.89 & 4 \\
\hline \multirow[t]{6}{*}{$\begin{array}{l}\text { NSC's } \\
\text { incompetency }\end{array}$} & \multirow[t]{6}{*}{4.49} & \multirow[t]{6}{*}{2} & $\begin{array}{l}\text { Check on the NSC's experience, proficiency and capacity to } \\
\text { deliver quality work on time }\end{array}$ & 4.18 & 1 \\
\hline & & & $\begin{array}{l}\text { Substantiate technical abilities through the qualifications of } \\
\text { directors, management and supervisory staff and the number } \\
\text { of skilled and semi-skilled labourers who are permanent } \\
\text { employees of the companies }\end{array}$ & 3.82 & 2 \\
\hline & & & Provide for a performance bond & 3.78 & 3 \\
\hline & & & Supervise well the NSC's works & 3.62 & 4 \\
\hline & & & Make subcontractor registration mandatory & 3.44 & 5 \\
\hline & & & $\begin{array}{l}\text { Use the quality assurance system of contractors to select } \\
\text { subcontractors }\end{array}$ & 3.42 & 6 \\
\hline \multirow{5}{*}{$\begin{array}{l}\text { Defects in } \\
\text { NSC's works }\end{array}$} & \multirow[t]{5}{*}{4.45} & \multirow[t]{5}{*}{3} & Implement a quality management system & 4.05 & 1 \\
\hline & & & $\begin{array}{l}\text { Make quality certification and occupational licensing } \\
\text { compulsory }\end{array}$ & 4.00 & 2 \\
\hline & & & Assure appropriate skills & 3.78 & 3 \\
\hline & & & Adopt zero defect initiative/policy & 3.76 & 4 \\
\hline & & & $\begin{array}{l}\text { Check quarterly reports submitted to maintain ISO } \\
\text { standards }\end{array}$ & 3.47 & 5 \\
\hline \multirow{7}{*}{$\begin{array}{l}\text { Inefficiency of } \\
\text { NSC's } \\
\text { employees }\end{array}$} & \multirow[t]{7}{*}{4.38} & \multirow[t]{7}{*}{4} & Ensure that properly trained employees work at site & 4.22 & 1 \\
\hline & & & Avoid overloading the NSC with many projects & 3.93 & 2 \\
\hline & & & $\begin{array}{l}\text { Allow clauses related to liquidated damages in the tender } \\
\text { document }\end{array}$ & 3.87 & 3 \\
\hline & & & Pay proper attention to the NSC's works & 3.84 & 4 \\
\hline & & & Provide project specific training & 3.71 & 5 \\
\hline & & & Pay for the quantity of work done & 3.58 & 6 \\
\hline & & & Maintain proper co-ordination with relevant parties & 3.51 & 7 \\
\hline \multirow[t]{2}{*}{ NSC insolvency } & \multirow[t]{2}{*}{4.20} & \multirow[t]{2}{*}{5} & $\begin{array}{l}\text { Check on the financial capacity, substantiated by audited } \\
\text { accounts that show their assets and liabilities, profits and } \\
\text { losses of the past several years }\end{array}$ & 4.31 & 1 \\
\hline & & & $\begin{array}{l}\text { Check on the credentials of the companies including job } \\
\text { references, past performance records, projects in hand }\end{array}$ & 4.25 & 2 \\
\hline
\end{tabular}




\begin{tabular}{|c|c|c|c|c|c|}
\hline \multirow[t]{7}{*}{ Issue } & \multirow[t]{7}{*}{ MR } & \multirow[t]{7}{*}{ 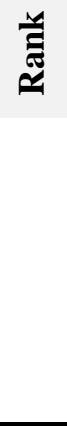 } & Solutions & MR & 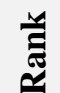 \\
\hline & & & Obtain advance payment security & 4.16 & 3 \\
\hline & & & Obtain a performance bond & 4.15 & 4 \\
\hline & & & Check credibility before awarding the subcontract & 4.02 & 5 \\
\hline & & & Avoid use of direct contract & 3.33 & 6 \\
\hline & & & $\begin{array}{l}\text { Add provisions in the contract to deal with bankruptcy of the } \\
\text { NSC }\end{array}$ & 3.22 & 7 \\
\hline & & & Establish a project bank account & 2.56 & 8 \\
\hline \multirow{4}{*}{$\begin{array}{l}\text { Imperfection in } \\
\text { MC-NSC } \\
\text { relationship }\end{array}$} & \multirow[t]{4}{*}{3.98} & \multirow[t]{4}{*}{6} & Develop better communications & 4.18 & 1 \\
\hline & & & Implement contract management and contract administration & 4.04 & 2 \\
\hline & & & Obtain Feedback & 3.96 & 3 \\
\hline & & & $\begin{array}{l}\text { Conduct a background study before selection to check on } \\
\text { NSC's working relations with the MC }\end{array}$ & 3.56 & 4 \\
\hline \multirow{5}{*}{$\begin{array}{l}\text { Imperfection in } \\
\text { MC-NSC } \\
\text { relationship } \\
\text { (Cont'd) }\end{array}$} & \multirow{9}{*}{$\begin{array}{c} \\
3.89\end{array}$} & \multirow{9}{*}{7} & $\begin{array}{l}\text { Reduce the number of layers/ tiers of subcontracting to } \\
\text { effectively manage the communication gap }\end{array}$ & 3.55 & 5 \\
\hline & & & Select the NSC early & 3.29 & 6 \\
\hline & & & Adopt partnering & 3.24 & 7 \\
\hline & & & Appoint a facilitator for management & 3.04 & 8 \\
\hline & & & Let MC and NSC decide on the staff jointly & 2.91 & 9 \\
\hline \multirow{4}{*}{$\begin{array}{l}\text { Inability of the } \\
\text { MC to control } \\
\text { the NSC }\end{array}$} & & & Have a separate project management system & 3.53 & 1 \\
\hline & & & Avoid direct payment clauses & 3.47 & 2 \\
\hline & & & Keep to formalities & 3.33 & 3 \\
\hline & & & Observe main contractor-subcontractor relationship & 3.09 & 4 \\
\hline \multirow{3}{*}{$\begin{array}{l}\text { NSC's } \\
\text { reluctance to } \\
\text { spend money on } \\
\text { health and safety }\end{array}$} & \multirow[t]{3}{*}{3.87} & \multirow[t]{3}{*}{8} & Allow provisions for safety when pricing & 4.27 & 1 \\
\hline & & & Make/inculcate safety culture at sites & 4.16 & 2 \\
\hline & & & Make MC to provide safety equipment, site doctor etc. & 3.65 & 3 \\
\hline \multirow{7}{*}{$\begin{array}{l}\text { High wastage of } \\
\text { materials by the } \\
\text { NSC }\end{array}$} & \multirow[t]{7}{*}{3.78} & \multirow[t]{7}{*}{9} & Use construction materials effectively & 4.35 & 1 \\
\hline & & & Identify waste management solutions & 4.00 & 2 \\
\hline & & & Develop efficient and convenient ways to deal with waste & 3.87 & 3 \\
\hline & & & Provide proper training to workers to avoid wasteful practices & 3.85 & 4 \\
\hline & & & Avoid errors in the calculation of materials & 3.75 & 5 \\
\hline & & & Introduce reusing or recycling processes & 3.55 & 6 \\
\hline & & & $\begin{array}{l}\text { Select the subcontractor early to allow him to get more } \\
\text { involved with the design }\end{array}$ & 3.45 & 7 \\
\hline \multirow{4}{*}{$\begin{array}{l}\text { NSC's Poor } \\
\text { awareness on } \\
\text { health and safety }\end{array}$} & \multirow[t]{4}{*}{3.73} & \multirow[t]{4}{*}{10} & $\begin{array}{l}\text { Use health and safety environment and make staff aware } \\
\text { of it }\end{array}$ & 4.31 & 1 \\
\hline & & & Appoint supervisory personnel & 3.84 & 2 \\
\hline & & & $\begin{array}{l}\text { Let the NSCs learn to work safely through common sense and } \\
\text { watching others and observing their mistakes }\end{array}$ & 3.69 & 3 \\
\hline & & & Provide off-the job training & 3.65 & 4 \\
\hline
\end{tabular}

Table 5. Criticalness of issues that can arise due to improper selection of NSCs and the importance of solutions that will resolve those issues

There were ten issues that were identified from the both the literature and the interviews, as arising due to improper selection of NSCs. The data collected from the respondents revealed that 'Delays caused by the NSC' is the most critical issue with a mean rating of 4.64 . Furthermore, $70.91 \%$ of the respondents have ranked this issue as 'very critical'. The second most critical issue has been identified as the 'NSC's incompetency' which has got a mean rating of 4.49. The third most critical issue is 'Defects in NSC's works' with $58.18 \%$ of the 
respondents considering this issue as "very critical'.

The solutions that will resolve these issues were ranked by the respondents of the questionnaire survey to identify the most suitable solution for each issue. To overcome the issue - 'Delays caused by the NSC'-, the solution - 'Make the NSC's program to fall in line with the MC's program' - has been identified to be the most important solution with a mean rating of 4.31 with $54.55 \%$ of the respondents considering it as 'very important'. The second most important solution has been identified as 'Allow clauses related to liquidated damages or/and penalties in the tender document' followed by 'Get the NSC to have a proper program' as the third most important solution.

With regard to the issue - 'NSC's incompetency' - which has got a mean rating of 4.18, the solution - 'Check on the NSC's experience, proficiency and capacity to deliver quality work on time'- has been identified as the best solution with $54.55 \%$ of the respondents ranking it as 'very important'. The second most important solution identified for this issue is 'Substantiate technical abilities through the qualifications of directors, management and supervisory staff and the number of skilled and semi-skilled labourers who are permanent employees of the companies'. The third most important solution is found to be 'Provide for a performance bond'.

The most suitable solution to resolve the issue - 'Defects in NSC's works' - is to 'Implement a quality management system' receiving a mean rating of 4.05 . The solutions - 'Make quality certification and occupational licensing compulsory' and 'Assure appropriate skills' - have been considered as the next most important solutions with mean ratings of 4.00 and 3.78 respectively.

\subsection{Criticalness of Issues related to Poor Documentation and the Importance of the Solutions that will resolve them}

The criticalness of the issues related to poor documentation and the importance of the solutions that will resolve those issues were ascertained from the questionnaire survey and the findings are given in Table 6 .

\begin{tabular}{|c|c|c|c|c|c|}
\hline Issue & MR & 产 & Solutions & MR & 音 \\
\hline \multirow{5}{*}{$\begin{array}{l}\text { Errors in } \\
\text { documentation }\end{array}$} & \multirow[t]{5}{*}{4.67} & \multirow[t]{5}{*}{1} & Prepare the specifications and the scope of work well & 4.65 & 1 \\
\hline & & & $\begin{array}{l}\text { Produce quality documentation that is concise, unambiguous, } \\
\text { consistent and complete }\end{array}$ & 4.51 & 2 \\
\hline & & & Provide all information to the subcontractor & 4.47 & 3 \\
\hline & & & $\begin{array}{l}\text { Have a proper definition for the scope of works of the } \\
\text { subcontractor }\end{array}$ & 4.40 & 4 \\
\hline & & & Get another party to carry out a document audit & 4.09 & 5 \\
\hline \multirow{3}{*}{$\begin{array}{l}\text { Discrepancies } \\
\text { between } \\
\text { specifications and } \\
\text { design drawings }\end{array}$} & \multirow[t]{3}{*}{4.58} & \multirow[t]{3}{*}{2} & $\begin{array}{l}\text { Coordinate properly the various disciplines to avoid } \\
\text { discrepancies }\end{array}$ & 4.35 & 1 \\
\hline & & & Get the architect to issue coordinated drawings & 4.04 & 2 \\
\hline & & & $\begin{array}{l}\text { Appoint a team leader to check on the accuracy of the } \\
\text { drawings }\end{array}$ & 3.98 & 3 \\
\hline \multirow[t]{4}{*}{ Design changes } & \multirow[t]{4}{*}{4.45} & \multirow[t]{4}{*}{3} & Maintain accuracy of the drawings and specifications & 4.58 & 1 \\
\hline & & & Appoint a person for design coordination & 3.93 & 2 \\
\hline & & & Complete all design documentation before calling for tenders & 3.87 & 3 \\
\hline & & & $\begin{array}{l}\text { Arrange partnering at the design development stage to } \\
\text { check on the design }\end{array}$ & 3.85 & 4 \\
\hline
\end{tabular}




\begin{tabular}{|c|c|c|c|c|c|}
\hline & & & $\begin{array}{l}\text { Add provisions in the contract to make the NSC liable for the } \\
\text { accuracy of designs }\end{array}$ & 3.69 & 5 \\
\hline \multirow{3}{*}{$\begin{array}{l}\text { Weakness in } \\
\text { keeping records of } \\
\text { work progress, } \\
\text { variation orders and } \\
\text { payment claims }\end{array}$} & \multirow[t]{3}{*}{4.42} & \multirow[t]{3}{*}{4} & $\begin{array}{l}\text { Follow up with the main contractor and subcontractor to ensure } \\
\text { that there is no delay in subcontractor's payments and main } \\
\text { contractor's insolvency }\end{array}$ & 4.58 & 1 \\
\hline & & & Monitor closely and keep records & 4.38 & 2 \\
\hline & & & Make it compulsory to maintain ISO standards & 4.11 & 3 \\
\hline \multirow{2}{*}{$\begin{array}{l}\text { Errors in subcontract } \\
\text { agreements }\end{array}$} & \multirow[t]{2}{*}{4.22} & \multirow[t]{2}{*}{5} & Use standard subcontract forms & 4.20 & 1 \\
\hline & & & Prepare accurate tender documents & 4.18 & 2 \\
\hline \multirow[t]{3}{*}{$\begin{array}{l}\text { Non submission of } \\
\text { programme on time }\end{array}$} & \multirow[t]{3}{*}{4.15} & \multirow[t]{3}{*}{6} & $\begin{array}{l}\text { Check on the compatibility with the main contractor's } \\
\text { programme }\end{array}$ & 4.35 & 1 \\
\hline & & & Make it mandatory to submit a programme with the tender & 4.20 & 2 \\
\hline & & & Arrange proper project management & 4.18 & 3 \\
\hline \multirow{2}{*}{$\begin{array}{l}\text { Wrong procedure } \\
\text { for subcontract } \\
\text { inquiry/ bid } \\
\text { document practised } \\
\text { in Sri Lanka }\end{array}$} & \multirow[t]{2}{*}{3.73} & \multirow[t]{2}{*}{7} & $\begin{array}{l}\text { Sign subcontract agreements which should include } \\
\text { necessary terms and conditions }\end{array}$ & 4.35 & 1 \\
\hline & & & Use standard forms of subcontracts & 4.25 & 2 \\
\hline
\end{tabular}

Table 6. Criticalness of issues related to poor documentation and the importance of the solutions that will resolve them

There were six issues identified from the literature synthesis to be as arising from poor documentation with only one issue identified through semi-structured interviews. The issue identified through the interviews is 'Wrong procedure for subcontract inquiry/ bid document practised in Sri Lanka'. Interviewee IB mentioned that the practice in Sri Lanka is to send a set of drawings to the NSC by the employer requesting for a quotation and that thereafter the main contractor is informed to use that particular subcontractor for certain identified specialised works. This simply means that the NSC will be appointed before preparing specifications, preambles, scope, design, interface, terms, conditions, programme and warranties.

The respondents of the questionnaire survey were requested to rank the criticalness of each issue and the results obtained are given in Table 6. The issue - 'Errors in documentation' - with a mean rating of 4.67 has been identified as the most critical issue related to improper documentation and
$67.27 \%$ of the respondents have considered it as 'very critical'. The second and third most critical issues identified were 'Discrepancies between specifications and design drawings' and 'Design changes'.

According to the information presented in Table 6, the solution - 'Prepare the specifications and the scope of work well' with a mean rating of 4.65 has been ranked as the best solution for the issue - 'Errors in documentation' - followed by 'Produce quality documentation that is concise, unambiguous, consistent and complete' and 'Provide all information to the subcontractor' in that order. However, Interviewee IB believed that providing all information may not be practically possible at the stage concerned and that therefore it would suffice if only the essential information could be provided.

In order to address the issue - 'Discrepancies between specifications and design drawings' - , the solution - 'Coordinate properly the various disciplines to avoid discrepancies'which has received a mean rating of 4.35 has been ranked as the best solution and 
considered by $52.73 \%$ of the respondents as 'very important'. The solutions - 'Get the architect to issue coordinated drawings' and 'Appoint a team leader to check on the accuracy of the drawings' - have been ranked as the second and third most important solutions with mean ratings of 4.04 and 3.98 respectively. Interviewee IA expects the team leader to check on the discrepancies and inconsistencies of the design as a check on the accuracy of the drawings.

The most important solution identified for the issue - 'Design changes' is to 'Maintain accuracy of the drawings and specifications' which has received a mean rating of 4.58 with $67.27 \%$ of the respondents ranking it as 'very important'. The solutions - 'Appoint a person for design coordination' and 'Complete all design documentation before calling for tenders' - have been identified as the second and third best solutions.

\subsection{Criticalness of Issues related to Improper Payment Modes and the Importance of the Solutions that will resolve them}

During the questionnaire survey, the respondents were asked to rank the issues related to improper payment modes and their solutions in order to identify the criticalness of the issues and the importance of solutions that will resolve them. The findings are presented in Table 7.

\begin{tabular}{|c|c|c|c|c|c|}
\hline Issue & MR & 気 & Solutions & MR & 气ี \\
\hline \multirow{3}{*}{$\begin{array}{l}\text { Delays in approving } \\
\text { the interim payment } \\
\text { certificate }\end{array}$} & \multirow[t]{3}{*}{4.65} & \multirow[t]{3}{*}{1} & $\begin{array}{l}\text { Attend to joint measurements, joint records and joint } \\
\text { reports prior to the submission of the application }\end{array}$ & 4.53 & 1 \\
\hline & & & $\begin{array}{l}\text { Ensure that the Engineer fulfils his responsibility } \\
\text { perfectly }\end{array}$ & 4.44 & 2 \\
\hline & & & Arrange proper project management and administration & 4.20 & 3 \\
\hline \multirow[t]{2}{*}{$\begin{array}{l}\text { MC not paying the } \\
\text { NSC on time }\end{array}$} & \multirow[t]{2}{*}{4.60} & \multirow[t]{2}{*}{2} & $\begin{array}{l}\text { Arrange proper project management including time } \\
\text { management and administration }\end{array}$ & 4.20 & 1 \\
\hline & & & Arrange effective Contract Administration & 4.05 & 2 \\
\hline \multirow{2}{*}{$\begin{array}{l}\text { MC applying set-offs } \\
\text { to payments }\end{array}$} & \multirow[t]{2}{*}{4.13} & \multirow[t]{2}{*}{3} & Arrange proper quality management to avoid defects & 4.35 & 1 \\
\hline & & & Add provisions to avoid unreasonable set-offs & 4.29 & 2 \\
\hline \multirow[t]{2}{*}{$\begin{array}{l}\text { MC applying set-offs } \\
\text { to payments (Cont'd) }\end{array}$} & & & $\begin{array}{l}\text { Add provisions to ensure that MC issues notice prior to } \\
\text { setting-off }\end{array}$ & 4.09 & 3 \\
\hline & & & Consider 'Pay now, argue later' concept & 3.82 & 4 \\
\hline
\end{tabular}

Table 7. Criticalness of the issues related to improper payment modes and the importance of the solutions that will resolve them

From the literature synthesis, three issues were identified as arising from improper payments. The respondents of the questionnaire survey were requested to rank the criticalness of each of those issues. The issue - 'Delays in approving the interim payment certificate' - with a mean rating of 4.65 has been identified as the most critical issue arising from improper payment modes. The issue- 'MC not paying the NSC on time'has been identified as the second most critical issue with a mean rating of 4.60 followed by 'MC applying set-offs to payments' as the third most critical issue. Interviewee IC said that in Sri Lanka, in order to maintain good relationships, the parties concerned often tend to avoid setting off unless it is the only available option. The issue - 'MC applying set-offs to payments' - has therefore received the lowest rank.

According to the information presented in Table 7, the most important solution that will resolve the issue- 'Delays in approving the 
interim payment certificate'- is to 'Attend to joint measurements, joint records and joint reports prior to the submission of the application' which received a mean rating of 4.53. The solutions- 'Ensure that the Engineer fulfils his responsibility perfectly' and 'Arrange proper project management and administration'- have been ranked next with mean ratings of 4.44 and 4.20 respectively.

The most important solution identified for the issue, 'MC not paying the NSC on time' is to 'Arrange proper project management including time management and administration' which has received a mean rating of 4.20. The solution - 'Arrange effective Contract Administration' - has been declared as the second best solution having a mean rating of 4.05 .

In order to address the issue, 'MC applying set-offs to payments', the solution - 'Arrange proper quality management to avoid defects' - with a mean rating of 4.35 has been identified as the best solution followed by 'Add provisions to avoid unreasonable setoffs', 'Add provisions to ensure MC issues notice prior to setting-off' and 'Consider 'Pay now, argue later' concept' with mean ratings of 4.29, 4.09 and 3.82 respectively. However, Interviewees IA and ID said that in Sri Lanka 'Pay now, argue later' concept is not being practiced very much. Interviewee IB mentioned that in Sri Lanka, a provisional amount is paid or a due amount on the undisputed part is paid.

\section{Conclusions}

Construction projects involve nominated subcontracting considerably and thus the management of NSCs has become crucial to ensure satisfactory project performance. However, nominated subcontracting practices in Sri Lanka are somewhat informal. Therefore, the nominated subcontracting practices in Sri Lanka were compared with those in other countries (Singapore, UK, Hong Kong and Australia).
It was identified that the method of selection of the NSC, type of the form of subcontract signed by the MC and the NSC and the 'pay when paid' payment mode used in Sri Lanka are similar to the practices in other countries. However, there are major differences as well. While the other countries use a form of subcontract developed to suit their particular requirements and their respective construction industries, Sri Lanka still uses the internationally accepted form of subcontract. On the other hand, unlike in other countries subcontractor registration is not compulsory in Sri Lanka and there is no security for payments made.

Because of the informal nature of the nominated subcontracting practices found in Sri Lanka, various issues tend to arise. Therefore, the issues arising from improper selection of the NSCs, poor documentation and improper payment modes and the solutions that will resolve them were investigated. There were 10 issues identified as arising from improper selection, 7 issues from poor documentation and 3 issues from improper payment modes. To resolve each of these issues, several solutions were identified. Thereafter, the significance of these issues and solutions were explored.

The most critical issue arising from the improper selection of a NSC is 'Delays caused by the NSC' and the most important solution for this issue is to 'Make the NSC's program to fall in line with the MC's program'. On the other hand, 'Errors in documentation' is identified as the most critical issue that can arise from improper documentation and 'Prepare the specifications and the scope of work well' is identified as the most important solution that will resolve this issue. The solution 'Arranging joint measurements, joint records and joint reports prior to the submission of application' - is considered as the most important solution to avoid the issue 'Delays in approving the interim payment 
certificate' - which can arise from improper payment modes. Hence, these solutions can be used to resolve issues arising from improper selection of NSCs, poor documentation and improper payments. Any further action necessary to improve the current nominated subcontracting practices in Sri Lanka can also be initiated.

\section{References}

Arditi, D. and Chotibhongs, R. (2005) Issues in subcontracting practice. Journal of Construction Engineering and Management, 131(8), pp. 866-876.

Anuruddhika, M.M.C., Perera, B.A.K.S. and Rodrigo, M.N.N. (2016) Management of Delays in Design and Build Projects undertaken in Sri Lanka. In Proceedings of the 12th International Conference of the International Institute for Infrastructure Resilience and Reconstruction, Kandy 5-7 August 2016. Kandy: Faculty of Engineering, University of Peradeniya, Sri Lanka: IIIRR, pp 191-198.

Artto, K., Eloranta, K. and Kujala, J. (2008) Subcontractors' business relationships as risk sources in project networks. International Journal of Managing Projects in Business, 5(4), pp. 578-594.

Attanayake, A.M.C. (2012). Factors affecting performance quality of subcontracting in Sri Lankan construction industry (Unpublished Bachelor's dissertation). University of Moratuwa, Sri Lanka.

Bandara, K. (1999). Issues on management of nominated subcontractors in Sri Lanka (Unpublished Bachelor's dissertation). University of Moratuwa, Sri Lanka.

Bennett, J. and Ferry, D. (1990) Specialist contractors: A review of issues raised by their new role in building. Construction Management and Economics, 8(3), pp. 259-283

Biong, H. (2013) Choice of subcontractor in markets with asymmetric information: reputation and price effects. Journal of Industrial Business and Marketing, 28(1), 60-71. doi:10.1108/08858621311285723

Bramble, B.B. and Callhan, M.T. (1992) Construction delay claims (2nd ed.). New York: John Wiley \& Sons.

Carnell, N.J. (2005) Causation and Delay in Construction. UK: Blackwell Publishing Ltd.

Cheng, T.Y.W., Soo, K.L., Kumaraswamy, M.M. and Wu, J. (2009) Security of payment for Hong Kong construction industry workable alternatives and suggestions. Building Journal Hong Kong China, 2(2), pp. 60-77.

Cho, J. and Furusaka, S. (2015) A Study on the Nomination of Nominated Subcontractor for Building Construction Projects in Singapore - Focusing on the Japanese Contractor's Projects. Journal of Architecture and Planning, 80(710), 933-941.

Chong, E.K. (1994) Project control of contractors in Singapore. BSc Dissertation, Singapore: National University of Singapore.

Construction Industry Council. (2013) Subcontractor Registration Scheme 2013. Retrieved from https://www.hkcic.org/eng/services/srs/index.aspx?langType=1033

Costantino, N., Pietroforte, R. and Hamill, P. (2001) Subcontracting in commercial and residential construction: an empirical investigation. Construction Management and Economics, 19(4), pp. 439-447.

Cunningham, T. (2013) Will the Construction Contracts Bill improve subcontractor cash flow? (Unpublished Bachelor's Dissertation) [online]. Dublin Institute of Technology. Available from http://arrow.dit.ie/cgi/viewcontent.cgi?article=1009\&context= beschreoth [Accessed 21 April 2015]

Debrah, Y.A. and Ofori, G. (1997) Flexibility, labour subcontracting and Human Resource Management in the construction industry in Singapore: can the system be refined? International Journal of Human Resource Management, 8, 690-709. doi: 10.1080/095851997341469

Department of Census and Statistics Sri Lanka (2013) Survey of construction industries [online]. Sri Lanka: Department of Census and Statistics. Available from: http://www.statistics.gov.lk/industry/SCI_Final_Report _2013.pdf [Accessed 10 April 2015]. 
Development Bureau of Hong Kong. (2015) Proposed Security of Payment Legislation for the Construction Industry [online]. Hong Kong: Development Bureau of Hong Kong. Available from: https://www.devb.gov.hk/filemanager/en/content_880/SOPL_Consultation_Document.pdf [Accessed 12 May 2016]

Dow, I., Sertyesilisik, B. and Ross, A.D. (2009) An investigation on the cost implications of methodology of subcontract work pricing. Journal of Financial Management of Property and Construction, 14(2), pp. 98-125.

Du Toit, J.L. and Mouton, J. (2013) A typology of designs for social research in the built environment. International Journal of Social Research Methodology, 16(2), pp. 125-139.

Ekanayake, E.M.K. and Perera, B.A.K.S. (2016) Appropriate delay analysis techniques to analyse delays in road construction projects in Sri Lanka, Built Environment Project and Asset Management, 6(5), 521 - 534

Enshassi, A., Arain, F.M., and Tayeh, B. (2010). Subcontractor prequalification practices in Palestine. International Journal of Construction Management, 10(4), 45-74. doi:10.1080/15623599.2010.10773154

Eriksson, P.E., Dickinson, M. and Khalfan, M.M.A. (2007) The influence of partnering and procurement on subcontractor involvement and innovation. Facilities, 25(5), 203-214. doi:10.1108/02632770710742174

FIDIC Conditions of Contract. (1999) FIDIC Conditions of Contract for Construction for Building and Engineering Works Designed by the Employer. (1st ed.). FIDIC

FIDIC Conditions of Subcontract. (2011) FIDIC Conditions of Subcontract for Construction for Building and Engineering Works Designed by the Employer. (1st ed.). FIDIC

Ganesharajah, T. (1999). Factors affecting subcontractors' bidding decisions in Sri Lanka (Unpublished Bachelor's dissertation). University of Moratuwa, Sri Lanka.

Greenwood, D. (2001) Subcontract procurement: are relationships changing? Construction Management and Economics, 19(1), 5-7. doi: 10.1080/0144619001000338

Hinze, J. and Tracey, A. (1994) The contractor-subcontractor relationship: The subcontractor's view. Journal of Construction Engineering and Management, 120(2), 274-287. doi:10.1061/(ASCE)07339364(1994)120:2(274)

Hughes, W., Gray, C. and Murdoch, J. (1994) Construction subcontracts: for what we are about to receive. In Proceedings of the 7th annual Construction Law Conference, London September 1994. London, UK, pp. 413442.

Humphreys, P., Matthews, J. and Kumaraswamy, M. (2003) Pre-construction project partnering: from adversarial to collaborative relationships. Supply Chain Management: An International Journal, 8(2), 166-178. doi:10.1108/13598540310468760

JCT Intermediate Named Sub-Contract. (2016) JCT Intermediate Named Sub-Contract Conditions 2016. UK: Joints Contracts Tribunal Limited

JCT Intermediate Sub-Contract. (2016) JCT Intermediate Sub-Contract Conditions 2016. UK: Joints Contracts Tribunal Limited

JCT Standard Building Sub-Contract. (2016) JCT Standard Building Sub-Contract Conditions 2016. UK: Joints Contracts Tribunal Limited

Kamarazaly, M.A. (2007), A mature profession of quantity surveying in Sri Lanka, (Unpublished MPhil thesis), University of Messay, Wellington.

Karim, K., Marosszeky, M. and Davis, S. (2006) Managing subcontractor supply chain for quality in construction. Engineering, Construction and Architectural Management, 13(1), pp. 27-42.

Kennedy, P., Morrison, A. and Milne, D.O. (1997) Resolution of disputes arising from set-off clauses between main contractors and subcontractors. Construction Management and Economics, 15(6), pp. 527-537.

Kian, C.C.C. (2000) Reflection on the Singapore Institute of Architects' Conditions. Singapore Academy of Law Journal, 12(1), 95-109.

Kwok, T.L. and Hampson, K.D. (1997) Strategic alliances between contractors and subcontractors - a tender evaluation criterion for the public works sector. In Proceedings of the International Conference on Construction Process Re-engineering. School of Engineering, Griffith University, Australia, pp. 671-684. 
Lai, L.W.C. (2000). The coasian market-firm dichotomy and subcontracting in the construction industry. Construction Management and Economics, 18(3), 355-362. doi: 10.1080/014461900370717

Loh W.H. and Ofori, G. (2000) Effect of registration on performance of construction subcontractors in Singapore. Engineering, Construction and Architectural Management, 7(1), 29-40. doi:10.1108/eb021130

Matthews, J., Tyler, A. and Thorpe, A. (1996) Pre-construction project partnering: developing the process. Engineering, Construction and Architectural Management, 3(1), pp. 117-131.

Mbachu, J. (2008) Conceptual framework for the assessment of subcontractors' eligibility and performance in the construction industry. Construction Management and Economics, 26(5), pp. 471-484.

McCord, P.J. and Gunderson, D.E. (2014). Factors that most affect relationships with general contractors on commercial construction projects: Pacific Northwest subcontractor perspectives. International Journal of Construction Education and Research, 10(2), 126-139. doi:10.1080/15578771.2013.856824

Mena, A., Lopez, F., Framinan, J.M., Flores, F. and Gallego, J.M. (2010) Improving the project documentation quality in the Spanish architectural, engineering and construction sector. Automation in Construction, 19(2), pp. 210-282.

Murdoch, J. and Hughes, W. (2000) Construction Contracts- Law and Management. (3rd ed.). London: Spon Press.

NEC3 Engineering and Construction Contract. (2013) NEC3 Engineering and Construction Contract. NEC

Ofori, G. (1990). The Construction Industry. Singapore: Singapore University Press.

Oseghale, G.E. and Wahab, A.B. (2014). Analysis of relationship between preliminary estimate, tender sum and final accounts. Civil and Environmental Research, 6(6), pp. 76-84.

Oxford dictionary. (2015). United Kingdom: Oxford University Express.

Rahman, I.A., Memon, A.H. and Karim, A.T.A. (2013) Significant factors causing cost overruns in large construction projects in Malaysia. Journal of Applied Sciences, 13(2), pp.286-293.

Rodrigo, M.N.N. and Perera, B.A.K.S. (2016) Selection of nominated subcontractors in commercial building construction in Sri Lanka. In Proceedings of 2nd international MERcon 2016: Moratuwa Engineering Research Conference, Moratuwa 5-6 April 2016. Moratuwa: Faculty of Engineering, University of Moratuwa, Sri Lanka, pp 210-215.

Ryder, M.P., Zuo, J. and Jin, X.H. (2013) Evaluating document quality in construction projects - subcontractors' perspective. International Journal of Construction Management, 13(3), pp. 77-94.

Saunders, P., Lewis, P. and Thornhill, A. (2009), Research Methods for Business Students, 5th ed., Edinburgh Gate, Harlow: Pearson Education Limited.

Sharkey, J., Bell, M., Jocic, W. and Marginean, R. (2014) Standard Forms of Contract in the Australian Construction Industry (Report No. 1, 1-60). Australia: University of Melbourne. Retrieved from http://www.law.unimelb.edu.au/staff/events/files/Research\%20report\%20-

\%20Standard\%20Forms\%20of\%20C ontract\%20in\%20the\%20Australian\%20Construction\%20Industry.pdf

Sivakumaran, S., Perera, B.A.K.S and Perera, K.T.P.K (2015) Construction Management as a Suitable Procurement Method for Hotel Building Construction in Sri Lanka. In Proceedings of the 19th Pacific Association of Quantity Surveyors Congress 2015, Japan, Pacific Association of Quantity Surveyors.

Skaik, S. and Al-Hajj, A. (2013) Improving the practice of subcontract nomination in the UAE construction industry. In Proceedings of the Conference on Construction, Building and Real Estate Research, India, 10-12 September 2013. India: New Delhi, RICS COBRA, pp. 1-13.

Standard Bidding Document, SBD-2, (2007) Standard Bidding Document Procurement of Works - Major Contracts. Sri Lanka: Institute of Construction Training and Development (ICTAD).

Thomas, S., Skitmore, M. and Chung, W.F. (2003) Ten basic factors to identify suitable subcontractors for construction projects. In proceedings of the CIB TG 23 International Conference on Professionalism in Construction: Culture of High Performance. Retrieved from http://eprints.qut.edu.au/64835/3/64835_Published_Version.pdf

Uher, T. and Davenport, P. (2009) Fundamentals of Building Contract Management (2nd ed.). Retrieved from https://books.google.lk/books?id=pObKMW gurOYC\&printsec=frontcover\#v=onepage\&q\&f=false 
Wong, W.F. and Cheah, C.Y.J. (2004) Issues of contractual chain and subcontracting in the construction industry. In: Khosrowshahi, F. (Ed.) Proceedings of the 20th Annual ARCOM Conference. 1-3 September 2004. Hariot Watt University, ARCOM, pp. 671-680.

Yates, D.J. and Hardcastle, C. (2003). The causes of conflict and disputes in the Hong Kong construction industry: A transaction cost economic perspective. RICS Foundation, 4(22).

Yik, F., Lai, J., Chan K.T. and Yiu, E. (2006) Best practices in managing specialist subcontracting performance. Hong Kong: Construction Industry Institute.

Zou, P.X.W. and Lim, B.T.H. (2006) An empirical study in subcontractor selection and long-term alliance relationship between Main Contractor and subcontractor. International Journal of Construction Management, 6(1), 1-13. doi:10.1080/15623599.2006.10773078 